\title{
The TP53 codon 72 polymorphism and predisposition to adrenocortical cancer in Polish patients
}

\author{
MAGDALENA IGNASZAK-SZCZEPANIAK ${ }^{1}$, WANDA HORST-SIKORSKA ${ }^{1}$, \\ JOANNA SAWICKA ${ }^{2}$, MARTA KACZMAREK ${ }^{3}$ and RYSZARD SLOMSKI ${ }^{3}$ \\ ${ }^{1}$ Family Medicine Department, Karol Marcinkowski University of Medical Sciences, \\ ul. Dabrowskiego 79, 60-529 Poznan; ${ }^{2}$ Department of Endocrinology and Internal Medicine, \\ Karol Marcinkowski University of Medical Sciences, ul. Przybyszewskiego 49, 60-355 Poznan; \\ ${ }^{3}$ Insitute of Human Genetics of Polish Academy of Sciences, ul. Strzeszynska 32, 60-223 Poznan, Poland
}

Received August 23, 2005; Accepted December 29, 2005

\begin{abstract}
The TP53 polymorphism occurs at codon 72 of exon 4 with two alleles encoding either arginine or proline. The association between this common polymorphism and risk of different cancers has been extensive studied, however various reports are controversial. We have analyzed the 72Pro polymorphic variant in patients with adrenocortical tumors to evaluate whether $72 \mathrm{G} \rightarrow \mathrm{C}$ substitution at codon 72 of TP53 gene may be associated with increased risk for malignancy in adrenal cortex in comparison to the control group. DNA extracted from peripheral leucocytes of 46 Polish patients with adrenocortical tumors (17 malignant and 29 benign) and 50 controls was examined by PCR-HD method followed by direct sequencing. TP53 polymorphism in codon 72 was found in $47 \%$ of ACC cases, in $28 \%$ of patients with adenomas and in $24 \%$ of controls. The genotype Arg/Arg, Arg/Pro and Pro/Pro distribution was respectively 53\%/ $35 \% / 12 \%$ for cancers, $72 \% / 28 \% / 0 \%$ for benign tumors and $76 \% / 24 \% / 0 \%$ for controls. High frequency of 72Pro allele in patients with carcinoma (29\%) in comparison to the benign tumors (14\%) and controls (12\%) was statistically analyzed. We found that 72Pro variant of TP53 gene was associated with a significantly increased risk of ACC (OR $=3.05 ; 95 \%$ $\mathrm{CI}=1.17-7.91, \mathrm{p}=0.03)$. Our results suggest that the TP53 codon 72 polymorphism could be associated with susceptibility for adrenocortical cancer in the examined Polish patients.
\end{abstract}

Correspondence to: Dr Magdalena Ignaszak-Szczepaniak, Family Medicine Department, Karol Marcinkowski University of Medical Sciences, ul. Przybyszewskiego 49, 60-355 Poznan, Poland E-mail: zmrw21@amp.edu.pl

Abbreviations: ACC, adrenocortical cancer; AA, adrenocortical adenoma

Key words: TP53 gene, codon 72 polymorphism, adrenocortical cancer, adrenocortical adenoma

\section{Introduction}

The TP53 tumor suppressor gene, located on chromosome $17 \mathrm{p} 13$, is one of the most important protectors of genomic integrity. It controls cell growth and division, detects DNA damage and is involved in the process of transcription of genes that are responsible for DNA repair and apoptosis $(1,2)$. The alterations in TP53 sequence which are associated with p53 protein inactivation are considered to play an important role in the process of carcinogenesis. Somatic mutations in TP53 gene are frequent genetic events observed in various human neoplasms with the frequencies varying from $10 \%$ to $60 \%(3,4)$. Germ-line mutations in TP53 are found in $70 \%$ families affected by Li-Fraumeni syndrome (LFS) and some of them are associated with familial predisposition to early onset cancers development in mutation carriers (5-7).

The polymorphisms in TP53 gene, defined as DNA sequence variations, are localized mainly in introns. The functional consequence of intronic variations are speculated. It has been suggested that mutations in intron sequences may initiate aberrant mRNA splicing, influence coding region mutations or affect DNA-protein interactions (8-10). Only five polymorphisms were found in coding regions (exons) at codons 21, 36, 47, 72 and 213. Three of them (21, 36 and 213) are silent and do not change amino acid sequence (11-13). The codon 47 polymorphism is rare (14), while polymorphism in codon 72 is common. In various reports, the codon 72 polymorphism was considered as a potential risk factor for different neoplasms, particularly in lung, skin and head and neck carcinomas, but results are controversial (15-17).

Tumors of adrenal cortex are rather common clinical problem. Most of the tumors are benign (adenomas, AA) non-functional (incidentalomas) or manifesting as endocrine syndromes (18). In contrast, adrenocortical cancer (ACC) is a very rare malignancy with an incidence of 1-2 per million population per year (19). This extremely aggressive neoplasm with very poor prognosis is a heterogeneous disease. Some patients survive $>5-10$ years despite metastasis, whereas in others a rapid progress not responding to any therapy is observed $(19,20)$. Several authors have attempted to predict prognosis on clinical, histological and molecular grounds 
Table I. Clinical and histopathological data of adrenocortical tumors $(n=46)$.

\begin{tabular}{lcc}
\hline & $\begin{array}{c}\text { Adrenocortical } \\
\text { carcinomas }\end{array}$ & $\begin{array}{c}\text { Adrenocortical } \\
\text { adenomas }\end{array}$ \\
\hline Number & 17 & 29 \\
Sex (F/M) & $11 / 6$ & $26 / 3$ \\
Median age (years) & $45(23-55)$ & $54(32-74)$ \\
Median size (cm) & $10(5-20)$ & $2.5(0.7-5.7)$ \\
Hormone secretion (n) & 6 & 12 \\
Incidentally found (n) & 11 & 17 \\
\hline
\end{tabular}

$(21,22)$. Some reports suggested a role for the TP53 somatic mutations in carcinogenesis in adrenal cortex but the main limitation of these studies is often the rarity of ACC (23-25). However, molecular studies that would allow to predict the risk of malignancy in adrenal cortex have not been performed so far. The aim of this study was to investigate whether a common polymorphism at codon 72 of the TP53 gene could predispose individuals to adrenocortical cancer development.

\section{Patients and methods}

Patients. A group of 46 Polish patients with adrenal tumors were investigated. Patients underwent clinical, radiological and hormonal evaluation. Final diagnosis was based on histopathological examination of adrenal tissues obtained at adrenalectomy. Grading of ACC was performed according to Weiss criteria of malignancy (26). Functional tumors were characterized by presence of typical clinical features and increased level of hormones (DHEA-S, aldosterone, cortisol, testosterone). MacFarlane criteria (27), modified by Sullivan et al (28), were used for determination of clinical stage of ACC. Twenty-nine tumors were diagnosed as benign (adenoma), including 12 hormonally active cases and 17 incidentally found. In 17 patients malignant neoplasm was diagnosed both functional $(n=6)$ and non-functional $(n=11)$. None of the patients had family cancer history and no family fulfilled Li-Fraumeni syndrome criteria. The control group comprised of 50 healthy unrelated individuals (25 men, 25 women) aged 40-55 years, without hormonal and radiological abnormalities in adrenal glands and with no family history of adrenocortical cancer. Histopathological and clinical data are summarized in Table I.

Methods. Peripheral blood $(5 \mathrm{ml})$ was collected from all patients. Genomic DNA was extracted from blood samples by standard procedure with guanidine izothiocyanate, followed by phenol/chloroform extraction. DNA was quantified by measuring absorbance with spectrophotometer. Exon 4 of TP53 gene were examined using initial amplification of DNA sample by polymerase chain reaction (PCR). DNA (125 ng) was amplified in $20 \mu \mathrm{l}$ PCR reaction mix containing: $2.5 \mathrm{nmol}$ of deoxinucleotide triphosphates (dNTPs), 15 pmol of forward and reverse primers, $1.5 \mathrm{mM} \mathrm{MgCl}_{2}, 1 \mathrm{U}$ Taq polymerase (Sigma), $1 \mathrm{X}$ buffer (Sigma). Primers sequences used for PCR were projected by use of the DNA Star Primer
Table II. Primer sequence and the length of PCR product.

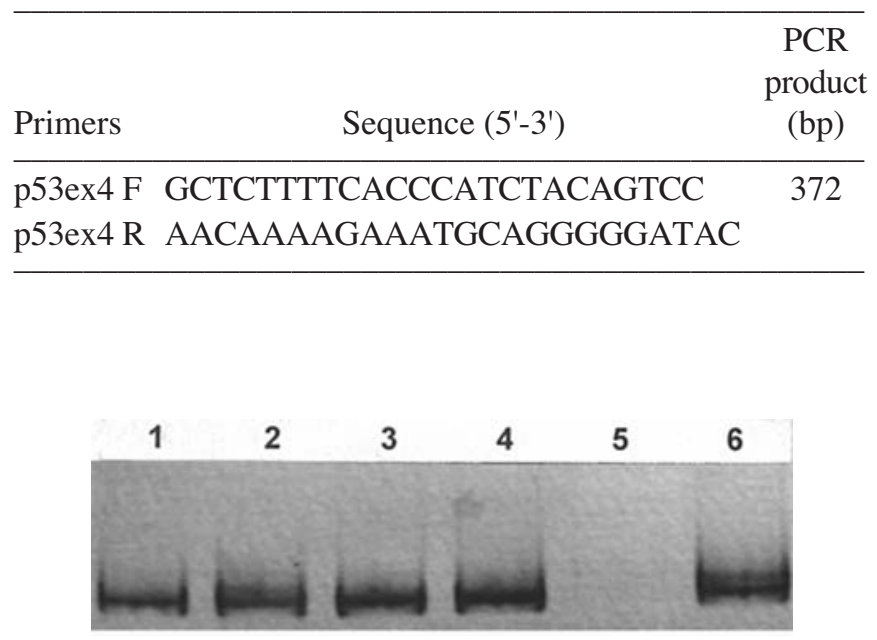

Figure 1. Fragment of the PCR-HD analysis of TP53 codon 72 in patients with adrenocortical cancer; in lanes 2 and 6 heteroduplex formations are shown.

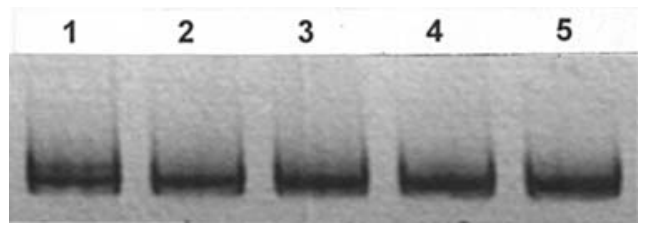

Figure 2. Example of the PCR-HD analysis of TP53 codon 72 in the control group; heteroduplex formation is seen in lane 1.

Select program (Table II). Initial denatu-ration at $95^{\circ} \mathrm{C}$ for $300 \mathrm{sec}$ was followed by 30 cycles of denaturation $\left(92^{\circ} \mathrm{C}\right)$ for $30 \mathrm{sec}$, annealing $\left(67^{\circ} \mathrm{C}\right)$ for $45 \mathrm{sec}$ and extension $\left(72^{\circ} \mathrm{C}\right)$ for $60 \mathrm{sec}$ in automated DNA Thermal Cycler (PTC-200, MJ Research). Samples without DNA were included as a negative control. Screening for the alterations in DNA sequence of examined coding regions was performed by heteroduplex analysis (HD). For products of amplification of exon 4 (372 bp) heat denaturation for $5 \mathrm{~min}$ at $95^{\circ} \mathrm{C}$ followed by reannealing at $65^{\circ} \mathrm{C}$ for $1 \mathrm{~h}$ was performed to induce heteroduplex formation. Samples were loaded on $10 \%$ native polyacrylamide gel and separated by vertical electrophoresis at $100 \mathrm{~V}$ for $10 \mathrm{~h}$. The silver staining reaction was used for DNA detection and differences in band patterns were searched for (Figs. 1 and 2). Furthermore, selected probes, in which heteroduplex occurred, were tested by cycle sequencing to confirm and identify sequence variation. Cycle sequencing reaction was performed using Cy5 dye labeled forward primers and ThermoSequenase Cycle Sequencing kit (USB) and ALFwin Sequence Analyzer 2.00.15 (Pharmacia Biotech). Examples of sequencing analysis are shown in Fig. 3.

Statistical analysis. Chi-square test was used to compare cases and controls for the polymorphism, genotype prevalence and allelic distribution. The association between the codon 72 polymorphism and both ACC and AA was estimated by calculating the odds ratios (ORs) and their $95 \%$ confidence 

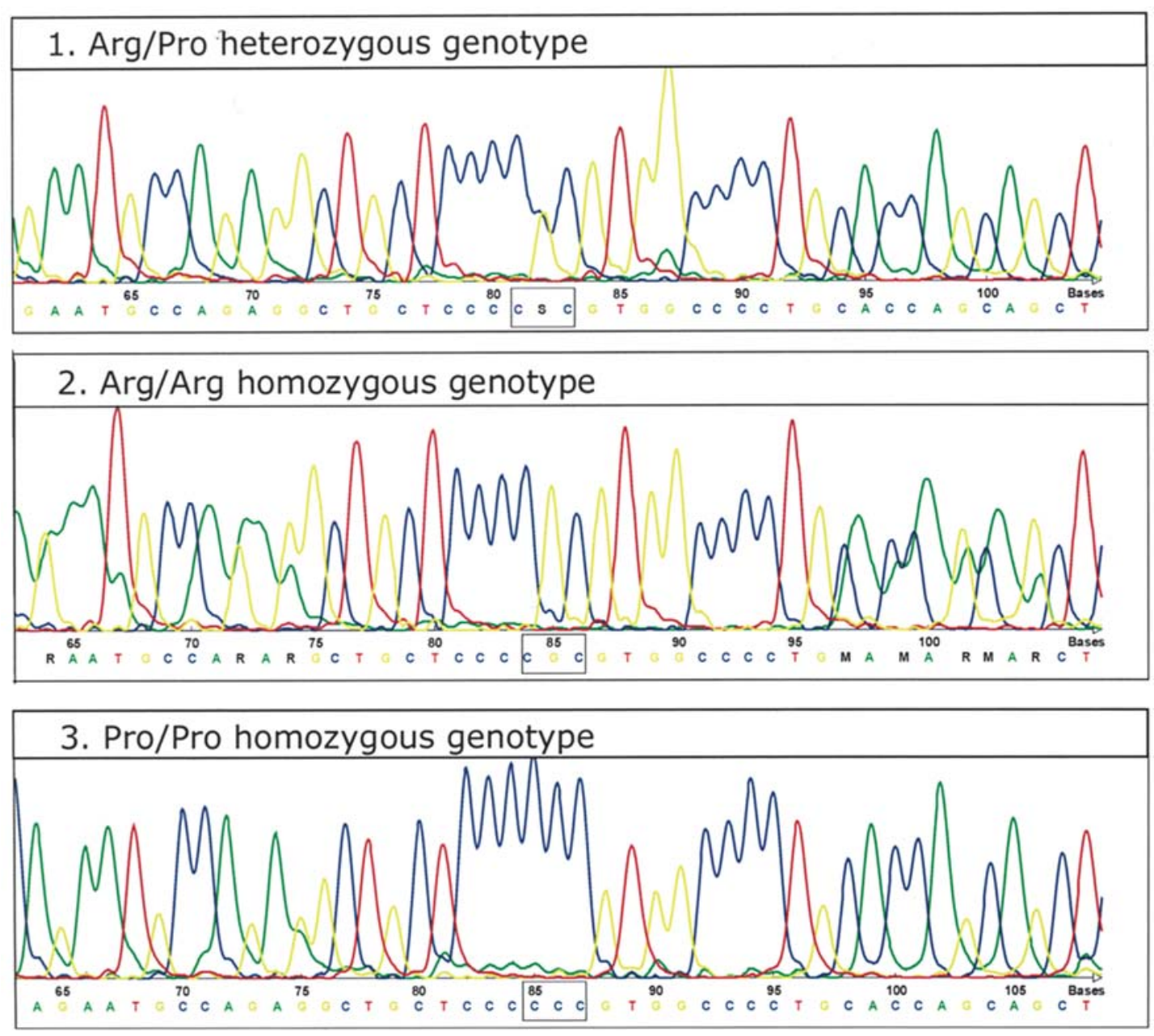

Figure 3. Sequencing analysis of the TP53 exon 4 showed G $\rightarrow$ C transversion in codon 72 and allowed to determine the genotype variants (Arg/Pro heterozygote, Arg/Arg and Pro/Pro homozygotes). Codon 72 is shown in frames.

intervals. Additional analyses were performed to detect the modification effect by sex and age. Data analysis was performed with Statistica v.6.1 (StatSoft Inc.) Statistical significance was set at $\mathrm{p}$-value $<0.05$.

\section{Results}

Females were overrepresented in the adenoma cases with men overrepresented in the controls. The mean ages were 45 years for carcinoma, 54 years for adenoma cases and 46 for the controls. Malignant tumors had significantly larger size than adenomas. Adrenocortical tumors were localized more often in the left adrenal gland.

The PCR-HD analysis of exon 4 followed by direct sequencing showed $72 \mathrm{G} \rightarrow \mathrm{C}$ substitution $(\mathrm{CGC} \rightarrow \mathrm{CCC})$ in 16 of 46 patients with adrenocortical tumors: in 8 of 17 carcinomas $(47 \%)$, in 8 of 29 adenomas (28\%). Genetic alterations in codon 72 was also detected in the control group with the frequency of $24 \%$. Additional analysis distinguished 3 genotypes: Arg/Arg, Arg/Pro, Pro/Pro according to alleles distribution. The Pro/Pro genotype was detected only in patients with adrenocortical carcinoma ( 2 of 17 cases, 12\%), while homozygous genotype Arg/Arg characterized 53\% and heterozygous Arg/Pro genotype was found in $35 \%$ of patients with malignant neoplasm. Distribution of the genotypes in the adenoma group was different: Arg/Arg showed $72 \%$ and Arg/Pro $28 \%$ of cases. None of the patients with benign tumor had the Pro/Pro genotype. Individuals from the control group revealed $24 \%$ of Arg/Pro genotype, the rest were homozygous for arginine. For the purpose of this analysis the Pro/Pro genotype was combined with Arg/Pro genotype because of the small number of homozygous Pro/Pro and to make possible the statistical calculation. Combined variant genotype group had 2.8-fold higher risk for adenocortical carcinoma than the Arg/Arg genotype $(\mathrm{OR}=2.8,95 \% \mathrm{CI}=$ $0.88-8.91)$ but no significance was observed $(\mathrm{p}=0.13)$. The same analysis was performed for adenoma cases. However, combined Arg/Pro + Pro/Pro genotype was not associated with the risk of AA $(\mathrm{OR}=1.2,95 \% \mathrm{CI}=0.42-3.41)$. Moreover, there was almost no difference in the genotype distribution between the adenoma patients and controls. The Arg/Arg variant genotype was taken as referent. Genotype distribution in the groups and odds ratios for adrenocortical carcinoma and adenoma are summarized in Table III.

The analysis of allele frequencies showed a high percentage of 72Pro polymorphic variant in patients with ACC $(29 \%)$ in comparison with the benign tumor cases (14\%). However, this substantial difference was not statistically 
Table III. Frequency distribution of TP53 gene genotypes among studied groups and its association with risk of ACC and AA.

\begin{tabular}{|c|c|c|c|c|c|c|c|c|}
\hline Genotype & $\begin{array}{l}\mathrm{ACC} \\
\mathrm{n}(\%)\end{array}$ & $\begin{array}{c}\text { Controls } \\
\mathrm{n}(\%)\end{array}$ & $\begin{array}{c}\text { OR } \\
(95 \% \mathrm{CI})\end{array}$ & p-value & $\begin{array}{c}\mathrm{AA} \\
\mathrm{n}(\%)\end{array}$ & $\begin{array}{c}\text { Controls } \\
\mathrm{n}(\%)\end{array}$ & $\begin{array}{c}\text { OR } \\
(95 \% \mathrm{CI})\end{array}$ & p-value \\
\hline Arg/Arg & $9(53)$ & $38(76)$ & Referent & & $21(72)$ & $38(76)$ & Referent & \\
\hline Arg/Pro + Pro/Pro & $8(47)$ & $12(24)$ & $2.81(0.88-8.91)$ & 0.13 & $8(28)$ & $12(24)$ & $1.20(0.42-3.41)$ & 0.93 \\
\hline
\end{tabular}

Table IV. Frequency distribution of TP53 alleles between patients and controls and its association with risk of ACC and AA.

\begin{tabular}{lcccccccc}
\hline Allele & $\begin{array}{c}\mathrm{ACC} \\
\mathrm{n}(\%)\end{array}$ & $\begin{array}{c}\text { Controls } \\
\mathrm{n}(\%)\end{array}$ & $\begin{array}{c}\text { OR } \\
(95 \% \mathrm{CI})\end{array}$ & $\mathrm{p}$-value & $\begin{array}{c}\text { AA } \\
\mathrm{n}(\%)\end{array}$ & $\begin{array}{c}\text { Controls } \\
\mathrm{n}(\%)\end{array}$ & $\begin{array}{c}\text { OR } \\
(95 \% \mathrm{CI})\end{array}$ \\
\hline 72Arg & $24(71)$ & $88(88)$ & Referent & & $50(86)$ & $88(88)$ & $\begin{array}{c}\text { Referent } \\
72(12)\end{array}$ \\
72 Pro & $10(29)$ & $12(12)$ & $3.05(1.17-7.92)$ & 0.03 & $8(14)$ & $12(12)$ & $1.17(0.44-3.06)$ & 0.74 \\
\hline
\end{tabular}

Table V. Stratification analyses of allelic frequencies and ORs for ACC by selected patient characteristics.

\begin{tabular}{|c|c|c|c|c|c|c|}
\hline & \multicolumn{2}{|c|}{ Cases } & \multicolumn{2}{|c|}{ Controls } & \multicolumn{2}{|c|}{ OR (95\% CI) } \\
\hline & 72Arg & 72Pro & 72Arg & 72Pro & 72Arg & 72Pro \\
\hline \multicolumn{7}{|l|}{ Age } \\
\hline$\leq 45$ & 11 & 5 & 47 & 7 & Ref. & $3.05(0.08-11.45)$ \\
\hline$>45$ & 13 & 5 & 41 & 5 & Ref. & $3.15(0.78-12.63)$ \\
\hline \multicolumn{7}{|l|}{ Sex } \\
\hline Female & 16 & 6 & 40 & 4 & Ref. & $3.75(0.93-15.08)$ \\
\hline Male & 8 & 4 & 48 & 8 & Ref. & $3.00(0.72-12.34)$ \\
\hline
\end{tabular}

significant $(\mathrm{p}=0.11)$. The comparison of the adenoma group and the controls had also no statistical significance $(p=0.74)$. Instead, we found statistically significant correlation comparing allelic variant frequencies in both carcinoma and control groups $(29 \%$ vs $12 \%, p=0.03)$. The carriers of the 72Pro allele had a 3.05-fold higher risk of adrenocortical cancer development $(\mathrm{OR}=3.05,95 \% \mathrm{CI}=1.17-7.92)$. The risk for benign tumor development in 72Pro carriers was not increased $(\mathrm{OR}=1.17,95 \% \mathrm{CI}=0.44-3.06)$. Allelic distribution and ORs for ACC and AA are shown in Table IV. For ACC cases the TP53 72Pro and 72Arg allele frequencies were further examined by stratification of selected factors (Table V). The association between 72Pro polymorphic allele and the risk of cancer was more pronounced in individuals $>45$ years $(\mathrm{OR}=3.15)$ in comparison to patients $\leq 45$ years. Moreover, women who were 72Pro allele carriers had higher risk of cancer $(\mathrm{OR}=3.75)$ than men $(\mathrm{OR}=3.00)$, however, this was not statistically significant $(\mathrm{p}=0.07)$.

\section{Discussion}

There are many reports on the TP53 codon 72 polymorphism that estimate a risk of cancer development in various ethnic groups and consider genotype distribution and allele frequencies in different human carcinomas. This is the first study examining the association between codon 72 polymorphism of the TP53 gene and the risk of adrenocortical tumors. This common polymorphism defined as $\mathrm{G} \rightarrow \mathrm{C}$ transversion leads to incorporation of proline (CCC) instead of arginine (CGC) in position 72 of p53 protein. Amino acid substitution is responsible for alteration in the structure and biological function of p53 protein and is considered to be associated with carcinogenesis.

We would like to emphasize that the current study concerns adrenocortical carcinomas that are one of the most rare cancers. The rarity of this malignancy is the main limitation of more numerous studies on ACC. Due to the low incidence it is difficult to gain experience in diagnosing and treating these tumors. Therefore, even reports with small number of patients (e.g. $23,24,47)$ that investigate molecular aspects of ACC development can be valuable to improve our knowledge on this cancer.

In our study, the TP53 codon 72 polymorphism occurred almost two times more frequently in patients with adrenocortical cancer $(47 \%)$ than in benign tumors $(28 \%)$ and controls (24\%). Despite marked difference in frequencies, no significance was observed when comparing ACC and the control group. The distribution of the TP53 codon 72 geno- 
types among the groups revealed that only patients with ACC were homozygous for the proline. Genotype Pro/Pro was not found in benign tumors or in the control group. Moreover, homozygous Pro/Pro genotype coexisted with malignant tumors sized $16-20 \mathrm{~cm}$, the largest diameters in the studied groups, but the very small number of cases $(n=2)$ excluded statistical analysis. Because the Pro/Pro genotype was infrequent we decided to combine subjects with Pro/Pro genotype with the Arg/Pro genotype to perform statistical calculation. The group with combined variant genotypes (Arg/Pro and Pro/Pro) had 2.8-fold higher risk of adenocortical carcinoma $(\mathrm{p}=0.13)$. We did not find an increased risk of adenomas in individuals with Arg/Pro genotype $(\mathrm{OR}=1.2)$. These results suggest the possibility of association between the genotype with the presence of one or both variant alleles and the susceptibility to adrenocortical cancer. The codon 72 of TP53 gene had no association with benign tumor development.

The analysis of allelic frequencies among cancer cases and controls revealed that the frequency of the TP53 72Pro allele in adrenocortical cancers was statistically different from controls $(29 \%$ versus $12 \%, \mathrm{p}=0.03)$. No statistical significance was observed when the variant 72 Pro frequencies were compared in benign tumors and controls $(p=0.74)$. Further analysis showed that the presence of polymorphic allele was a statistically significant risk factor for adrenocortical cancer. Individuals who were 72Pro allele carriers had 3.05-fold higher risk of ACC. These results indicate increased predisposition to cancer development in the 72Pro carriers and suggest an important role of 72Pro allele in adrenal carcinogenesis. Stratification for age showed slightly increased risk of ACC in patients older than 45 years in comparison to cases under 45 , but for both groups the risk exceeded 3.0. We also found higher, however, not statistically significant, risk of ACC in women with the 72Pro variant as compared to men, after stratification for sex. This finding is interesting because the presence of the polymorphic allele may be associated with a predominance of ACC in women, observed in different populations, but this hypothesis requires further examination $(19,20)$.

The estimation of polymorphic variant frequency in healthy Polish population would be important to determine the influence of the TP53 gene polymorphism on predisposition to adrenocortical cancer. Beckman et al showed that distribution of polymorphic variant in Europe oscillated from $17 \%$ for Swedish to $32 \%$ for southern Europe, but Polish were not considered in this study (29). We found only one report on the TP53 codon 72 polymorphism in 52 healthy Polish women (30). For comparable number of probes the genotype distribution in that study was similar to ours except homozygous Pro/Pro genotype. It is intriguing that in our research neither in the control group nor in adenoma group the Pro/Pro genotype was found. One possible explanation is a selection bias in the genotype distribution of the control group. The reason may also be a geographical and ethnic backgrounds as well as sex of the groups.

The association between the TP53 polymorphism at codon 72 and a risk of different cancers has been investigated in several studies. The role of both 72Pro and 72Arg variants as risk factors have been examined for carcinogenesis of the lung, cervix, breast, bladder, skin and head and neck. However, not all reports have been consistent. According to Kawaijiri et al (31) and Wu et al (32) the 72Pro allele was associated with an elevated risk of lung cancer, especially in Caucasian. It was shown (32) that distribution of genotype frequencies were strongly dependent on ethnicity. In another study, the presence of the polymorphic 72Pro form markedly increased risk of lung malignancy in male smokers from Chile (33). Fan et al (15) reported that the Arg/Pro and Pro/Pro genotypes contributed to a heritable susceptibility for smoke-induced lung carcinoma. Other studies showed either no association between polymorphism and lung cancer (35) or only slightly elevated association (34). Interestingly, several scientific groups have revealed the role of 72Arg allele in carcinogenesis. Papadakis et al (36) proved that homozygous Arg/Arg genotype was associated with advanced lung cancer and that Arg allele was preferentially retained in Arg/Pro germline heterozygotes. Storey et al (37) showed that homozygote Arg/Arg were seven times more susceptible to human papilloma virus-associated cervical cancer. Zehbe et al (38) also found that the TP53 codon 72 arginine homozygosity was a risk factor for cervical cancer in Swedish and Italian women, but other reports did not confirm this hypothesis (39-41). Increased risk of cancer development in patients homozygous for the arginine variant of TP53 codon 72 was also observed in bladder (42) and breast cancers (43). Other publications on correlation between the 72 codon polymorphism and a pre-disposition to breast, bladder and head and neck malignancies have not revealed statistically significant association for these cancers development $(44,45)$. Different results were also observed in skin neoplasm. The individuals with Pro/Pro genotype had increased risk of skin cancer in patients from Taiwan (17) while Americans diagnosed with cutaneous melanoma were at increased risk of the disease if they were homozygous for arginine (46). It seems that ethnicity and environmental factors as well as exposure to carcinogens could modulate the genetic predisposition and should be taken into account. Furthermore, biases in study design and various methodological features could explain the divergence of the results.

The polymorphism at codon 72 that results in amino acid substitution is responsible for alteration in the primary structure and different biological function of protein $(48,49)$. Thomas et al (49) noted differences between two p53 variants in their abilities to activate the expression of p53 responsive promoters, in activation of the transcription and the apoptosis induction. These investigations are important for genetic hypothesis of cancer development and may influence the response on chemotherapy $(50,51)$. Other researchers also reported functional differences between the polymorphic variants. Codon 72 is localized in the proline-rich domain of p53, between residues 61 and $94(1,2)$. This region has a crucial role for effective transduction of antiproliferative signals and is strongly connected with programmed cell death (52). Changes in the proline-rich domain markedly impair its ability to induce apoptosis. Dumont et al (48) reported that 72 Pro and $72 \mathrm{Arg}$ variants have different apoptotic potential. Moreover, p53 protein with arginine in position 72 indicates programmed cell death 5-10 times better then 72Pro variant. Lower apoptotic potential of the 72Pro 
variant may influence cancer development or treatment. On the other hand, the authors suggested that tumors containing 72Arg variant might be predicted to respond more favorable to radiation or chemotherapy.

In conclusion, this study showed that the presence of CCC sequence encoding proline at codon 72 of TP53 gene was significantly associated with increased risk of adrenocortical cancer. This finding suggests that 72Pro allele may be a risk factor for ACC, predisposing individuals to adrenocortical carcinogenesis. Additional larger population-based case-control studies on the TP53 codon 72 polymorphism as a genetic predictor for malignant transformation in adrenal cortex are required to confirm our findings.

\section{Acknowledgments}

Special thanks to Professor Anna Kasperlik-Zaluska for material used in our investigations. Our research and applied procedures were approved by the Ethics Committee of Karol Marcinkowski University of Medical Sciences (permit No. 72/03).

\section{References}

1. Schwab M (ed): Encyclopedic Reference of Cancer. SpringerVerlag, Berlin pp669-910, 2001.

2. Levine AJ: P53 the cellular gatekeeper for growth and division. Cell 88: 323-331, 1997.

3. Hainault P and Holstien M: P53 and human cancer: the first thousand mutation. Adv Cancer Res 77: 81-137, 2000.

4. Hollstein M, Sindransky D, Vogelstein B and Harris CC: P53 mutations in human cancers. Science 253: 49-53, 1991.

5. Olivier M, Goldgar DE, Sodha N, Ohgaki H, Kleihues P, Hainaut P and Eeles R: Li-Fraumeni and related syndromes; correlation between tumor type, family structure and TP53 genotype. Cancer Res 63: 6643-6650, 2003.

6. Kleihues P, Schauble B, zur Hausen A and Oghaki H: Tumors associated with p53 germline mutations. Am J Pathol 150: 1-13, 1997.

7. Nichols KE, Malkin D, Garber JE, Fraumeni JF and Li FP: Germ-line p53 mutations predispose to a wide spectrum of early onset cancers. Cancer Epidemiol Biomarkers Prev 10: 83-87, 2001.

8. Hillebrandtm S, Streffer C, Demidchik EP, Biko J and Reiners C: Polymorphism in the p53 gene in thyroid tumours and blood samples of children from areas of Belarus. Mutat Res 381: 201-207, 1997.

9. Malkinson AM and You M: The intronic structure of cancer related genes regulates susceptibility to cancer. Mol Carcinog 10: 61-65, 1994.

10. Lozano $G$ and Levine AJ: Tissue specific expression of p53 in transgenic mice is regulated by intron sequences. Mol Carcinog 4: 3-9, 1991.

11. Ahuja HG, Testa MP and Cline MJ: Variation in the protein coding region of the human p53 gene. Oncogene 5: 1409-1410, 1990.

12. Felix CA, Brown DL, Mitsudomi T, Ikagaki N, Wong A and Wasserman R: Polymorphism at codon 36 of the p53 gene. Br J Cancer 81: 179-183, 1999.

13. Carbone D, Chiba L and Mitsudomi T: Polymorphism at codon 213 within the p53 gene. Oncogene 6: 1691-1692, 1991

14. Felley-Bosco E, Weston A, Cawley HM, Bennett WB and Harris CC: Functional studies of a germ-line polymorphism at codon 47 within p53 gene. Am J Hum Genet 53: 752-759, 1993.

15. Fan R, Wu M, Miller D, Wain J, Kelsey K, Wiencke J and Christiani D: The p53 codon 72 polymorphism and lung cancer risk. Cancer Epidemiol Biomarkers Prev 9: 1037-1042, 2000.

16. Chen YC, Xu L, Guo YL, Su HJ, Hsueh YM, Smith TJ, Lee JY, Chaor SC and Christiani DC: Genetic polimorphism in p53 codon 72 and skin cancer in southwestern Taiwan. J Environ Sci Health Part A - Tox Hazard Subst Environ Eng 38: 201-211, 2003.
17. Scheckenbach K, Lieven O, Gotte K, Bockmuhl U, Zotz R, Bier H and Balz V: P53 codon 72 polymorphic variants, loss of allele-specific transcription and human papilloma virus 16 and/or E6 messenger RNA expression in squamous cell carcinomas of head and neck. Cancer Epidemiol Biomarkers Prev 13: 1805-1809, 2004.

18. Sidhu S, Gicquel C, Bambach CP, Campbell P, Magarey C, Robinson BG and Delbridge LW: Clinical and molecular aspects of adrenocortical tumorigenesis. ANZ J Surg 73: 727-738, 2003.

19. Latronico A and Chrousos G: Adrenocortical tumors. J Clin Endocrinol Metab 82: 1317-1324, 1997.

20. Allolio B, Hahner S, Weismann D and Fassnacht M: Managment of adernocortical carcinoma. Clin Endocrinol 60: 273-228, 2004.

21. Sredni ST, Zerbini MC, Latorre MR and Alves VAF: P53 as a prognostic factor in adrenocortical; tumors of adults and children. Braz J Med Biol Res 36: 23-27, 2003.

22. Gicquel C, Bertagna X, Gaston V, Coste J, Louvel A, Baudin E, Bertherat J, Chapuis Y, Duclos JM, Schlumberger M, Plouin PF, Luton JP and Le Bouc Y: Molecular markers and long-term recurrences in a large cohort of patients with sporadic adrenocortical tumors. Cancer Res 61: 6762-6767, 2001.

23. Reincke M, Karl M, Travis WH, Mastorakos G and Chrousos GP: P53 mutations in human adrenocortical neoplasms: immunohistochemical and molecular studies. J Clin Endocrinol Metab 78: 790-794, 1994.

24. Wachenfeld C, Bueschlein F, Zwermann O, Mora P, Fassnacht M, Allolio B and Reincke M: Discerning malignancy in adrenocortical tumors: are molecular markers useful? Eur J Endocrinol 145: 335-341, 2001.

25. Barzon L, Chilosi M, Fallo F, Martignoni G, Montagna L, Palu G and Boscaro M: Molecular analysis of CDKN1C and TP53 in sporadic adrenal tumor. Eur J Endocrinol 145: 207-212, 2001.

26. Weiss LM: Comperative histologic study of 43 metastasizing and non-metastasizing adrenocortical tumors. Am J Surg Pathol 8: 163-169, 1984.

27. MacFarlane DA: Cancer of the adrenal cortex: the natural history, prognosis and treatment in a study of 55 cases. Ann R Coll Surg Engl 23: 166-186, 1958.

28. Sullivan M, Boileau M and Hodges CC: Adrenal cortical carcinoma. J Urol 120: 660-665, 1997.

29. Beckman G, Birgander R, Sjalander A, Saha N and Beckman L: Is 553 polymorphism maintained by natural selection? Hum Hered 44: 266-270, 1994.

30. Dybikowska A, Dettlaff A, Konopa K and Podhajska A: P53 codon 72 polymorphism in cervical cancer patients and healthy women from Poland. Acta Biochim Pol 47: 1179-1182, 2000.

31. Kawaijiri K, Nakachi K, Imai K, Watanabe J and Hayashi S: Germ line polymorphisms of p53 and CYP1A1 genes involved in human lung cancer. Carcinogenesis 14: 1085-1089, 1993.

32. Wu X, Zhao H, Amos C, Shete S, Makan N, Hong WK, Kadlubar F and Spitz M: P53 genotypes and haplotypes associated with lung cancer susceptibility and ethnicity. J Natl Cancer Inst 94: 681-690, 2002.

33. Irarrazabal CE, Rojas C and Gil L: Chilean pilot study on the risk of lung cancer associated with codon 72 polymorphisms in the gene of protein p53. Toxicol Lett 15: 69-76, 2003.

34. Matakidou A, Eisen T and Houlston RS: TP53 polymorphisms and lung cancer: a systematic review and meta-analysis. Mutagenesis 18: 377-385, 2003.

35. Biros E, Kalina I, Kohut A, Stubna J and Salagovic J: Germ line polymorphisms of the tumor suppressor gene p53 and lung cancer. Lung Cancer 31: 157-162, 2001.

36. Papadakis ED, Soulitzis N and Spandidos DA: Association of p53 codon 72 polymorphism with advanced lung cancer: the Arg allele is preferentially retained in tumors arising in Arg/Pro germline heterozygotes. Br J Cancer 87: 1013-1018, 2002.

37. Storey A, Thomas M, Kalita A, Harwood C, Gardial D, Mantovani F, Brener J, Leigh IM, Matlashewski G and Banks L: P53 polymorphism and risk of cervical cancer. Nature 396: $532-535,1998$.

38. Zehbe I, Voglino G, Wilander E, et al: p53 codon 72 polymorphism and various human papillomavirus 16 E6 genotypes are risk factors for cervical cancer development. Cancer Res 61: 608-611, 2001

39. Rosenthal A, Ryan A, Al-Jehani R, Storey A, Harwood C and Jacobs I: P53 codon 72 polymorphism and risk of cervical cancer in UK. Lancet 352: 871-872, 1998. 
40. Cenci M, French D, Pisani T, Alderisio M, Lombardi AM, Marchese R, Colleli F and Vecchione A: P53 polymorphism at codon 72 is not a risk factor for cervical carcinogenesis in central Italy. Anticancer Res 23: 1385-1387, 2003.

41. Koushik A, Platt RW and Franco EL: P53 codon 72 polymorphism and cervical neoplasia: meta-analysis review. Cancer Epidemiol Biomarkers Prev 13: 11-22, 2004.

42. Soulitzis N, Sourvinos G, Dokianakis DN and Spandidos DA: p53 72 polymorphism and its association with bladder cancer. Cancer Lett 179: 175-183, 2002.

43. Papadakis EN, Dokianakis DN and Spandidos DA: p53 codon 72 polymorphism as a risk factor in the development of breast cancer. Mol Cell Biol Res Commun 3: 389-392, 2000.

44. Marbouk I, Baccouche S, El-Abed R, Mokdad-Gargouri R, Mosbah A, Said S, Daoud J, Frikha M, Jlidi R and Gargouri A: No evidence of correlation between p53 codon 72 polymorphism and risk of bladder or breast carcinoma in Tunisian patients. Ann NY Acad Sci 1010: 764-770, 2003.

45. Tiwawech D, Srivatanakul P, Karakul A and Ishida T: The p53 codon 72 polymorphism in Thai nasopharyngeal carcinoma. Cancer Lett 198: 69-75, 2003.

46. Shen H, Liu Z, Strom S, et al: p53 codon 72 Arg homozygotes are associated with an increased risk of cutaneous melanoma. J Invest Dermatol 121: 1510-1514, 2003.
47. Varley JM, McGown G, Thorncroft L, James L, Margison G, Forster G, Gareth D, Evans R, Harris M, Kelsey A and Birch J: Are there low-penetrance TP53 alleles? Evidence from childhood adrenocortical tumors. Am J Hum Genet 65: 995-1006, 1999.

48. Dumont P, Leu JI, Della Pietra AC III, George DL and Murphy M: The codon 72 polymorphic variants of p53 have markedly different apoptotic potential. Nat Genet 33: 357-365, 2003.

49. Thomas M, Kalita A, Pim D, Banks L and Matlashewski G: Two polymorphic variants of wild-type p53 differ biochemically and biologically. Mol Cell Biol 19: 1092-1100, 1999.

50. Bergamaschi G, Merante S, Orlandi E, Galli A, Bernasconi P and Cazzola M: TP53 codon 72 polymorphism in patients with chronic myeloid leucemia. Haematologia 89: 869-869, 2004.

51. Sullivan A, Syed N, Gasco M, Bergamaschi D, Trigiante G, Attard M, Hiller L, Farrell PJ, Smith P, Lu X and Crook T: Polymorphism in wild-type p53 modulates response to chemotherapy in vitro and in vivo. Oncogene 23: 3328-3337, 2004.

52. Walker KK and Levine AJ: Identification of a novel p53 functional domain that is necessary for efficient growth suppression. Proc Natl Acad Sci USA 93: 15335-15340, 1996. 